\title{
Clinical disorders affecting mesopic vision
}

\author{
A Petzold GT Plant
}

19.02.2006

\begin{abstract}
Vision in the mesopic range is affected by a number of inherited and acquired clinical disorders. Here we review these conditions and summarize the historical background, describe the clinical characteristics alongside the genetic basis and molecular biological mechanisms giving rise to rod and cone dysfunction relevant to twilight vision. The current diagnostic gold standards for each disease are discussed and curative and symptomatic treatment strategies are summarized.
\end{abstract}

Keywords: Autoimmune-related retinopathy and optic neuropathy (ARRON) syndrome, Bothnia dystrophy, cancer associated retinopathy, congenital stationary night blindness (CSNB), enhanced S-cone syndrome (ESCS), fundus albipunctatus, melanoma associated retinopathy, Newfoundland rod-cone dystrophy, Oguchi disease, retinitis pigmentosa (RP), retinitis punctata albescens, Sorsby fundus dystrophy, vitamin A deficiency (VAD). 


\section{Contents}

1 Introduction 3

2 Reduced vision in the mesopic range due to rod dysfunction 4 2.1 Hereditary conditions . . . . . . . . . . . . . . . 5

2.2 Acquired conditions . . . . . . . . . . . . . . . . 17

3 Reduced vision in the mesopic range related to cone dysfunction

4 Assessment

5 Conclusions

References 


\section{Introduction}

The visual system allows us to see over a remarkable range of illumination. In fact, the visual system covers about $11 \log _{10}$ units change in illumination (Stockman and Sharpe this issue). We can adapt to see in bright sun light relying purely on the cone system as well as in near complete darkness by switching to the more sensitive rod system. The transition from photopic (light) to scotopic (dark) vision is part of what is known as dark-adaptation. Mesopic vision refers to visual function at certain light levels (twilight) at which both the cone- and rod-system are active. Mesopic vision covers about 32 to 0,0032 Candela per centimeter square $\left(\mathrm{cd} / \mathrm{m}^{2}\right)$. It is important to remember that dark adaptation may take up to 40 minutes achieve full sensitivity. Mesopic vision depends on both the external light level and the speed of the biochemical processes providing the energy to turn the rodsystem fully on. Problems in mesopic vision are related to a pathological transition from photopic to scotopic vision and may present clinically as night blindness. The importance of rod function in mesopic conditions is exemplified by the fact that the contrast sensitivity of the rod system is highest at light levels where cones are also still contributing to vision.

The term "night blindness" was introduced by Brodley and, though not strictly accurate, is now in common use (Bordley, 1908). Alternative used terms include "nyctalopia" (seeing at night, preferred in the French literature) or "hemeralopia" (seeing in the day). Strictly speaking nyctalopia means day blindness, e.g. in cone monochromacy. There is much controversy around the correct use for these terms with the Anglo-Saxon literature directly opposing the French literature (Duke-Elder, 1963; Skinner, 1970; Brouzas et al., 2001). In this review we refer to "impaired night vi- 
sion" when we use the term "night blindness".

In developed societies photopic conditions extend beyond the daylight hours. That is to say many of us will rarely employ scotopic vision and paracentral vision in the mesopic range is only needed under certain circumstances. One of the most important situations in which most of us still rely on mesopic vision (rods and cones are active) is driving. There are however certain work environments, leisure and sport activities were peripheral vision and hence rod signals are important, even at high levels of scene luminance e.g., $10 \mathrm{~cd} / \mathrm{m}^{2}$.

Vision in the mesopic range can be impaired in a number of diseases, some of which are inherited and others are acquired. Here we review these disorders and try to differentiate how they may affect mesopic vision rather than pure rod (scotopic) vision. Additionally, we discuss how cone dysfunction may also impair the early transition from photopic to mesopic vision. Finally we propose a short guideline for investigating these patients including the cardinal clinical features and history, the relevant investigations and treatment options.

\section{Reduced vision in the mesopic range due to rod dysfunction}

Here we review the human conditions in which rod dysfunction leads to slow dark adaptation and consequently to impaired vision in the mesopic range. It is worth remembering that although the biochemical processes driving rod function may be slowed due to defective enzymes, in many instances the cellular metabolism permits adaptation such that normal rod function may be observed after prolonged periods of dark adaption. 


\subsection{Hereditary conditions}

A genetic mutation affecting any single protein or enzyme involved in the retinoid processing cycle potentially causes retinal disease (reviewed by Lamb and Pugh (Lamb and Pugh EN, 2004)). The five diseases relevant to the present review are retinitis pigmentosa, retinitis pigmentata alibscens, Bothnia dystrophy (BD), fundus albipunctatus, Congenital stationary night blindness and Oguchi disease.

Retinitis pigmentosa comprises the largest group and three genetically distinct variants, retinitis punctata albescens, Bothnia dystrophy, and Newfoundland rod-cone dystrophy will be discussed separately.

Retinitis pigmentosa (RP) Retinitis pigmentosa (RP), a clinically and genetically heterogeneous group of disorders, is the most common hereditary cause for visual impairment in all age groups. It has a prevalence of approximately 1:3500 (Pagon, 1988; Phelan and Bok, 2000).

The classical symptoms of night blindness at early age and bilateral peripheral VF loss are predominantly observed in patients with rod-cone RP. Although macular vision is relatively preserved, cone degeneration in the later phases of the disease will affect central VA and day vision. Progression to legal blindness may happen as early as in the third or as late as in the sixth decade (Berson, 1996). Complete blindness occurs in a proportion of RP patients. It is not possible to predict speed and extent of visual failure.

Patients who present with loss of central vision, night blindness and VF loss are likely to suffer from cone-rod dystrophy/degeneration, a RP allied disease (Phelan and Bok, 2000).

The age of onset of symptoms is related to the mode of inheritance 
with children being more likely to suffer from $\mathrm{X}$-linked RP, whilst younger to older adults are more likely to suffer from autosomal recessive or autosomal dominant RP, respectively (Weleber, 1994). The increasing number of RP genes (Hims et al., 2003; Delyfer et al., 2004) is regularly updated on RetNet (www.sph.uth.tmc.edu/Retnet). The classification of these genes into functional classes is complex. Phelan and Bok classified these into 7 main functional groups (1) the visual cascade, (2) the visual cycle, (3) tetraspanins, (4) photoreceptor cell transcription factors, (5) catabolic functions in the retina, (6) mitochondrial genes and (7) genes of yet unknown function (for review see (Phelan and Bok, 2000) and references therein). Kalloniatis and Fletcher recently reviewed the underlying biological mechanisms (Kalloniatis and Fletcher, 2004).

Fundus examination shows the typical picture of a mottled or granular appearance of the retina early in the disease (Figure 1) which develops into bone-spicule pigmentary deposits overlying the depigmented retina (Figure 2) (Phelan and Bok, 2000). There is some variation in the appearance of pigmentary changes and window-like holes through the RPE are observed as are hypopigmentation, translucence and accumulation of pigment deposits of circular shape. Retinal atrophy results in attenuation of the retinal blood vessels and a pale disc due to loss of the nerve fibre layer (Phelan and Bok, 2000; Weleber, 1994; Heckenlively, 1988).

Electroretinography plays a central role in the diagnosis of RP (see (Heckenlively, 1988; Marmor and Zrenner, 1998-99) and references therein). In the classical picture of rod degeneration abnormalities in the scotopic ERG precede those in the photopic ERG. In contrast in RP allied diseases presenting with cone-rod dystrophy the photopic ERG becomes abnormal first (Phelan and Bok, 2000). Occasionally a disproportional disruption of 

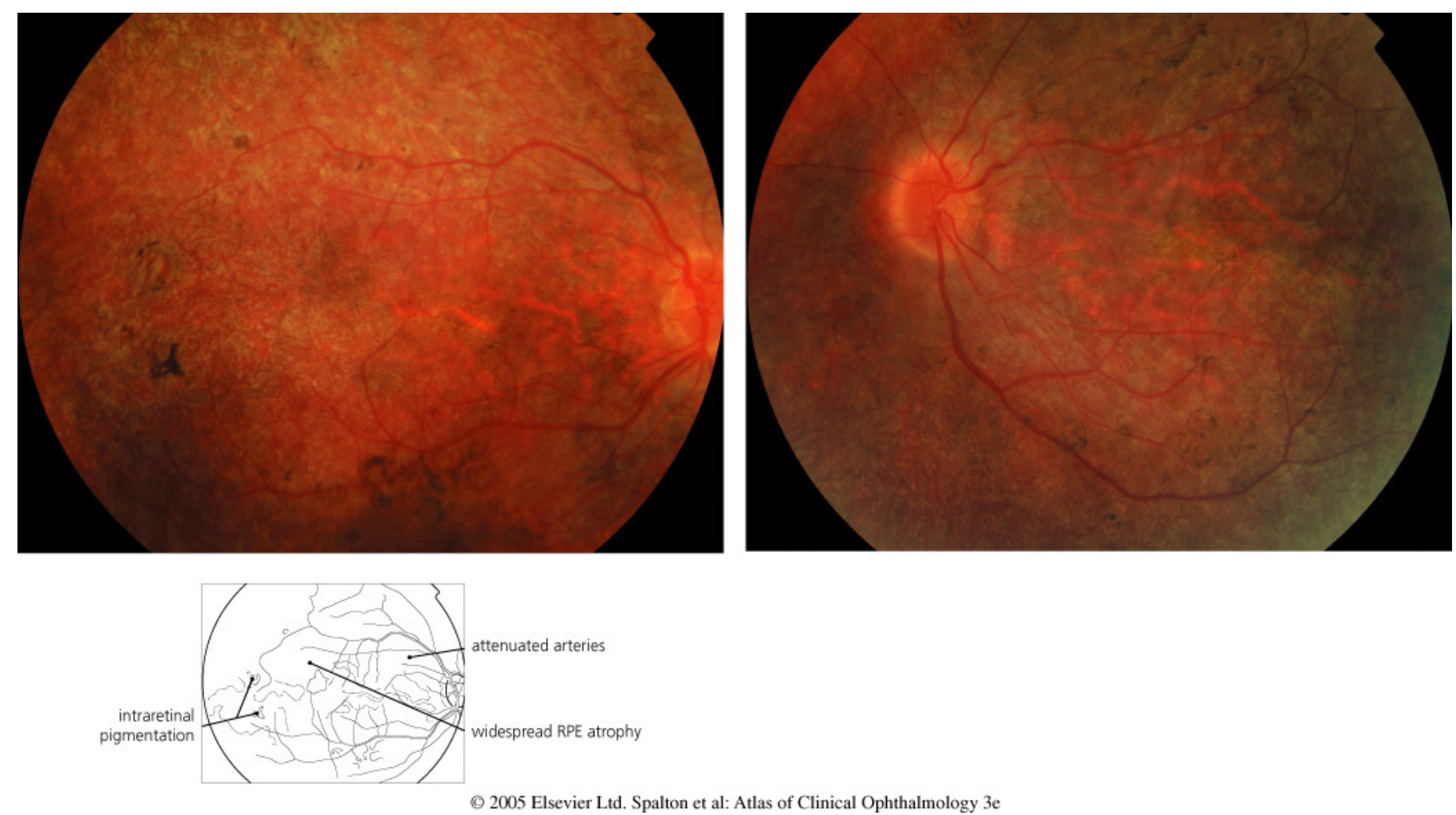

Figure 1: Retinitis pigmentosa, in a child showing the early development of a pigmentary retinopathy with optic disc pallor and retinal arteriolar narrowing (reprocuced with permission from reference (Spalton et al., 2005)). 

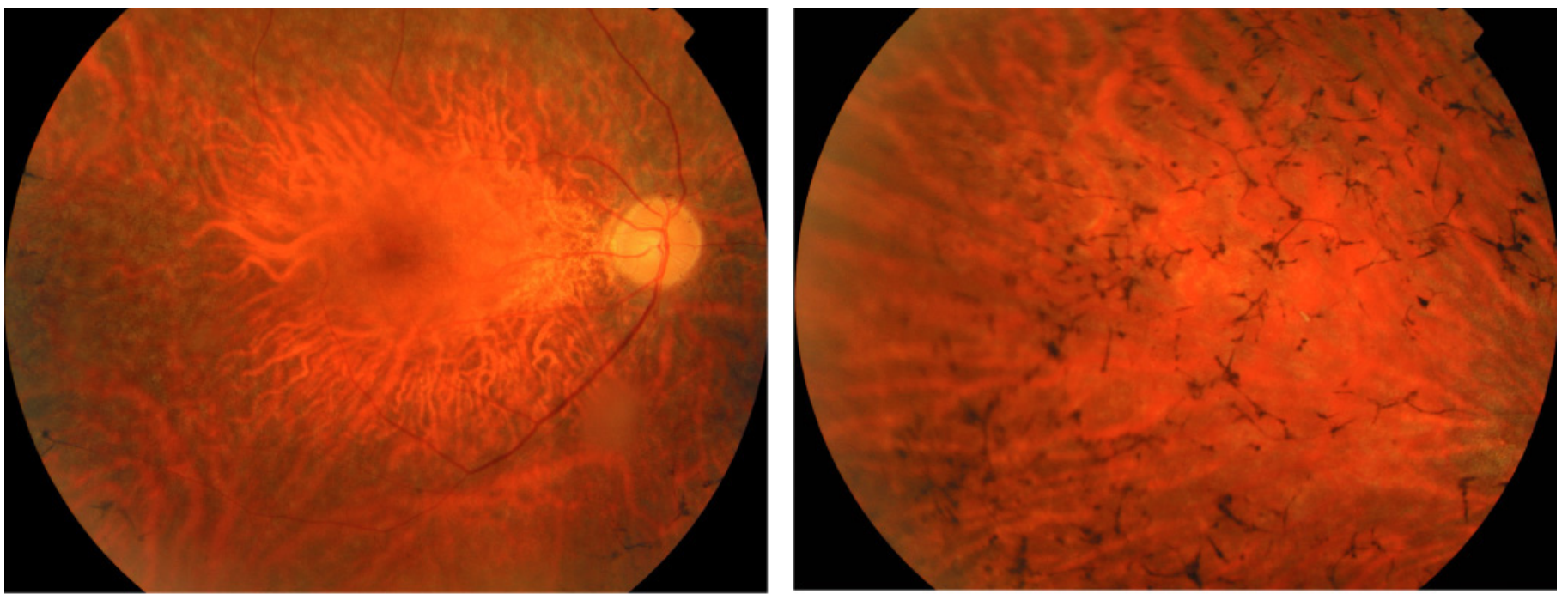

(1) 2005 Elsevier Ltd. Spalton et al: Atlas of Clinical Ophthalmology 3e

Figure 2: Retinitis pigmentosa, the fundus appearance in early disease may be variable sometimes including mild pigment epithelial atrophy in the mid-periphery and small white dots at the level of the RPE. The typical bone spicule pigment deposition is typically seen later in the disease. (reproduced with permission from reference (Spalton et al., 2005)). 
the photoreceptor component of the ERG b-wave is observed represented as an electronegative ERG. An absent ERG response is seen in the endstages of the disease. There are anecdotal reports of an abnormal ERG preceding the onset of clinical symptoms later in life. In those cases where parents are affected by RP, but no gene has yet been identified this may occasionally be an issue for counseling and investigating the children.

There is no curative therapy available in RP yet. Low vision management remains one of the most valuable symptomatic treatment options (Weiss, 1991). This includes providing best refraction. The use of electronic means of magnification using special settings for the computer screen is extremely valuable and complements the common magnifying glass. Where a complaint of glare is related to cataract this is amenable to surgery. Glare may also be controlled by spectacle glasses incorporationg short-wavelength filters. Care has to be taken that appropriate levels of illumination are provided for visual tasks. A range of VF enhancing device have been used with a varying degree of success and other strategies such as a blind walking cane or systematic scanning techniques are other alternatives. Counseling and ancillary care complement above (for review see (Weiss, 1991)). Genetic counselling poses a particular challenge (Gross-Jendroska et al., 1992). Dietary supplementation with vitamin $A$ at a daily dose of 15,000 IU (international units) may slow the progression of RP in the early stages of the disease (Berson et al., 1993). Patients should avoid taking vitamin E supplements, because this may hasten the disease, possibly by reducing the amount of vitamin $A$ reaching the eye (Berson, 1996). There are a number of controversial treatment strategies not reviewed here (see (Kalloniatis and Fletcher, 2004; Delyfer et al., 2004) and references therein). There is experimental evidence an- 
imals that genetherapy and specifically gene replacement therapy, may be an exciting avenue to be pursued (for review see (Rolling, 2004) and references therein).

Retinitis punctata albescens (RPA) Retinitis punctata albescens (RPA) is a rare progressive, autosomal recessive disorder caused by a number of different mutations in a number of genes (Nakamura et al., 2005; Burstedt et al., 2005, 2003; Granse et al., 2001; Burstedt et al., 2001, 1999; Weiss et al., 1992; Morimura et al., 1999; Fishman et al., 2004). The affected genes are the Retinaldehyde-Binding Protein 1 (RLBP1) gene, the peripherin/RDS gene, the rhodopsin gene. The Arg135Trp point mutation in the rhodopsin gene was discovered by Souied in 1996 (Souied et al., 1996) and the RLBP1 mutation was first described by Maw in 1997 (Maw et al., 1997).

Patients usually present in early childhood with night blindness (Nakamura et al., 2005; Morimura et al., 1999). As the disease progresses visual acuity decreases and visual fields become restricted.

The examination of the fundus demonstrates whitish spots throughout the fundus (Figure 3), sometimes with a annulus appearance round the macula (Nakamura et al., 2005; Morimura et al., 1999). With loss of the nerve fibre layer the retinal vasculature becomes more attenuated (Morimura et al., 1999).

Fluorescein angiogram may show granular hyperfluorescence of the retina and window defects over the macula (Nakamura et al., 2005).

Optical coherence tomography (OCT) has been used to demonstrate thinning of the retina around the macula, mainly affecting the outer nuclear layer (Nakamura et al., 2005). 

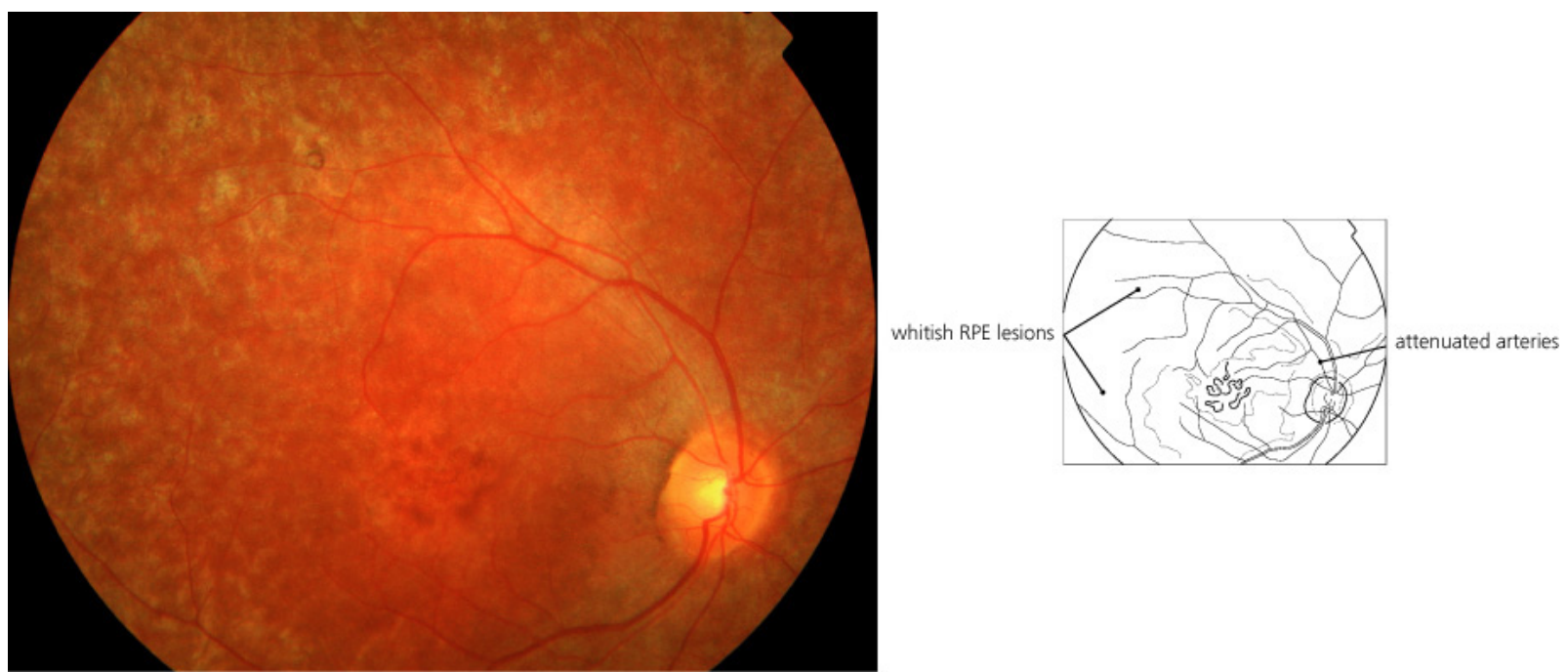

(1) 2005 Elsevier Ltd. Spalton et al: Atlas of Clinical Ophthalmology 3e

Figure 3: Retinitis punctata albescens, multiple white deposits scattered throughout the retina are seen alongside macular atrophy. (reproduced with permission from reference (Spalton et al., 2005)). 
The ERG is severely abnormal, if not unrecordable for all modalities (photopic, scotopic and mesopic) (Nakamura et al., 2005; Morimura et al., 1999). Scotopic blue seems to be particularly vulnerable (Morimura et al., 1999).

The differential diagnosis includes RP and Nakamura and colleagues make the point that although the examination of the fundus shows distinctive subretinal flecks in FA, additional genetic analysis may be required (Nakamura et al., 2005).

Bothnia dystrophy (BD) Bothnia dystrophy (BD) represents a subgroup of RPA patients with less severe disease due (Burstedt et al., 1999, 2001). These patients are homozygous for the RLBP1 mutation Arg234Trp and were from northern Sweden. They have a predilection to exhibit an atrophicappearing macular lesion, particularly when over the age of 30 .

There is no specific treatment.

Newfoundland rod-cone dystrophy (NFRCD) Newfoundland rod-cone dystrophy (NFRCD) represents another subgroup of RP patients with a particular phenotype due to a mutation in the RLBP1 gene (Eichers et al., 2002). The onset of the disease is early ( $<10$ years of age) and rapidly progresses so that legal blindness is usually reached between the age of 40-50 years. Night blindness is the earliest symptom, followed by progressive loss of peripheral, central and colour vision.

The fundus appearance is somehow distinct to what is observed in RP or $\mathrm{BD}$. In contrast to RP, there are usually no bone spicule pigmentations until late in the disease. In contrast to BD the macular appears normal or shows a "beaten-bronze" atrophy (Eichers et al., 2002). The observed 
white stippling of the retina and annulus around the macula is similar to what is observed in RPA.

The rod ERG is affected early in the disease, followed by an abnormal cone ERG (Eichers et al., 2002).

There is no specific treatment.

Congenital stationary night blindness (CSNB) Congenital stationary night blindness (CSNB) is an umbrella term for a heterogeneous, nonprogressive group of disorders presenting in childhood with night blindness and occasionally other ocular symptoms such as nystagmus, decreased visual acuity, myopia and hyperopia (Zeitz et al., 2005; Abramowicz et al., 2005; Weleber, 2002; Wutz et al., 2002; Lorenz et al., 1996). The autosomal dominant variant of CSNB was first described in the Nougaret family by the Belgian ophthalmologist Florent Cunier (Cunier, 1838; JP, 2001) in collaboration with a local antiquarian (M Chauvet) from a small village near to Montpelier. The founder of this family was a French butcher by the name of Jean Nougaret born in Provence in 1636. The Nougaret family was followed up by Nettleship (Nettleship, 1907).

Whilst many genes are described the underlying biochemical features are not yet unraveled and more functional studies are needed (Muradov et al., 2003; Mansergh et al., 2005). There is a recent report of benign familial myoclonic epilepsy in 3 patients with CSNB suggesting that some of these patients may suffer from a channelopathy (Manabe et al., 2002) which is consistent with the findings in a new animal model (Mansergh et al., 2005).

The fundus may appear normal, and this variant is referred to as the Schubert-Bornschein variant (Schubert and Bornschein, 1952). 
The ERG responses in X-linked and autosomal recessive CSNB show a selective reduction of the $b$-wave, whilst the a-wave is almost completely normal, giving rise to the typical picture of the a-wave being larger than the b-wave (Miyake et al., 1986, 1994; Bradshaw et al., 2004; Langrova et al., 2002), a so-called "negative" ERG. Differences in the rod and cone b-wave responses permit to distinguish CSNB1 from CSNB2 (Zeitz et al., 2005). The ERG allows for further sub classification of the SchubertBornschein variant dependent on whether the defect of the bipolar cells is complete or incomplete (Schubert and Bornschein, 1952; Miyake et al., 1986).

The discovery of new phenotypes makes the interpretation of the ERG more complex and there is no clear genotype phenotype correlation (Kabanarou et al., 2004; Allen et al., 2003).

Fundus albipunctatus Fundus albipunctatus (FA), first described by Lauber in 1910 (Lauber, 1910) presents with non-progressive, or very slowly progressive night-blindness without associated retinal dystrophy. The typical clinical findings are multiple whitish yellow spots in the fundus which tend to be scattered as an annulus around the macular (Figure 4). FA can present with and without macular atrophy (Nakamura et al., 2003).

FA is caused by a number of distinct mutations in the RDH5 gene which encodes for the 11-cis retinol dehydrogenase of the retinal pigment epithelium (Nakamura et al., 2003; Nakamura and Miyake, 2002). The biological function of this enzyme is to oxidises the alcohol 11-cis retinol to the aldehyde 11-cis retinal. Impairment of this process results in reduced retinol delivery and prolonged dark-adaptation.

The interesting finding is that patients suffer from severely depressed 
Review: mesopic vision and disease

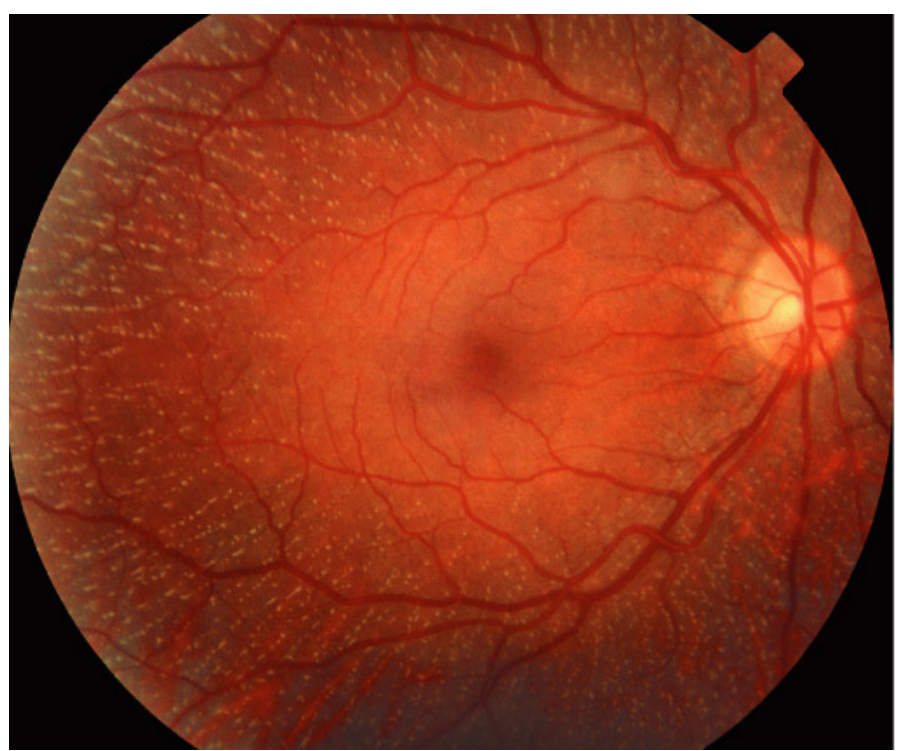

Figure 4: Fundus albipunctatus. The characteristic fundus appearance with multiple white dots scattered over the retina with macular sparing is shown (reproduced with permission from reference (Spalton et al., 2005)). 
rod-function in the early stages of dark adaptation. However, rod function starts to improve within about 30 minutes of adaptation and returns to near normal levels after 2-3 hours of adaptation. (Carr et al., 1974). The biochemical basis for this phenomenon is delayed regeneration of rod visual pigment. It is of note that this also delays the regeneration of cone visual pigments. In fact cone dysfunction can be demonstrated in about $38 \%$ of patients with FA (Cideciyan et al., 2000; Niwa et al., 2005). Macular lesions are not required for reduced cone function.

There is no specific therapy for fundus albipunctatus.

Oguchi disease Oguchi disease is a non-progressive disorder first described by Oguchi in 1912 (Oguchi, 1912) in which dark adaptation is 8 to 10-times slower than normal (Carr and Ripps, 1967; Sharp et al., 1990; Cideciyan et al., 1998). Mizuo (Mizuo, 1913) observed in these patients by examination of the fundus that under light adapted conditions the retina had a metallic, phosphorescence-like sheen which disappears with prolonged dark adaptation, a phenomenon which had since carried his name. Interestingly pigment regeneration appears to be normal despite a severely reduced dark adaptation (Lamb and Pugh EN, 2004). Oguchi disease is caused by mutations in genes encoding either of two proteins, RR or Arr (reviewed in (Dryja, 2000)). These mutations are more common in the Japanese compared to the European population.

Standard full field scotopic ERG shows absent rod responses and a reduced a-wave. The cone and flicker ERG is normal. The photopic ERG permits differentiation of patients with Oguchi disease from complete CSNB where the ON response is reduced (Miyake et al., 1996). 


\subsection{Acquired conditions}

Vitamin A deficiency (VAD) Vitamin A deficiency (VAD), defined by serum retinol concentration $<0.7 \mu \mathrm{mol} / \mathrm{L}$ is world wide the most common cause for xeropthalmia (xeros, dry, ophthalmia, inflamed eye) which is followed by night blindness (Tielsch and Sommer, 1984). Although recognized since the early Egyptian times (Wolf, 1978), the typical fundus appearance was not described until 1928 by Uyemura (Uyemura, 1928). Fuchs subsequently proposed the name the disease Uyemura syndrome (Fuchs, 1928; Fuch, 1959).

VAD is a public health issue in countries with part of the population faces nutritional problems. VAD has recently been described in Afghanistan (Mihora et al., 2004), Bangladesh (de Pee et al., 2003; Singh and West KP, 2004; Ahmed et al., 2000; Ahmed, 1999), Bhutan (Singh and West KP, 2004), Brazil (Saunders et al., 2004; Ramalho et al., 2002), Cambodia (Semba et al., 2003; Christian, 2002), Djibouti (Resnikoff et al., 1992), Ethiopia (Asrat et al., 2002; Haidar and Demissie, 1999), India (Shaw et al., 2005; Singh and West KP, 2004; Christian, 2002), Indonesia (de Pee et al., 2003; Singh and West KP, 2004; Mele et al., 1991), Iraq (Al-Kubaisy et al., 2002), Kenya (Nabakwe et al., 2005), Kiribatie (Schaumberg et al., 1996), Malaysia (Ngah et al., 2002), Mali (Schemann et al., 2002; Farbos et al., 2000), the Marshall Islands (Maqsood et al., 2004), Myanmar (Singh and West KP, 2004), Nepal (Taren et al., 2004; Singh and West KP, 2004), Niger (Blum et al., 2004), Nigeria (Oso et al., 2003), Philippines (Rosen et al., 1994), Sri Lanka (Singh and West KP, 2004; Brink et al., 1979), Tanzania (Wedner et al., 2000), Thailand (Singh and West KP, 2004; Bloem et al., 1989), Yemen (Rosen et al., 1996), Zaire (Donnen et al., 1996), Java (Bergen HR et al., 1988), Malawi (Tielsch et al., 1986). Xerophthalmia re- 
mains the leading cause of acquired pediatric blindness. The WHO estimates that about 140-250 million world wide are at risk of a vitamin A deficiency disorder (Underwood, 2004).

The earliest symptom of VAD is night blindness, followed by peripheral and central visual field constriction (McBain et al., 2005), photophobia, and reduced visual acuity. The revised WHO (1981) clinical classification of xeropthalmia includes night blindness, conjunctival xerosis, Bitot spots, corneal xerosis, corneal ulceration/keratomalacia, corneal scarring, xeropthalmia fundus (Sommer, 1982). Photopic stress to the rods can exacerbate night blindness by up regulating the rhodopsin turnover (Baillie, 1816; Stephenson, 1896).

Vitamin $A$ is one of the five fat-soluble vitamins essential to human metabolism. Amongst other functions it is needed to synthesize rhodopsin, the visual pigment used in the rods and cones (McBain et al., 2005).

The differential diagnosis for VAD is wide and apart from patients suffering from malnutrition in the mentioned areas (Mihora et al., 2004; de Pee et al., 2003; Singh and West KP, 2004; Ahmed et al., 2000; Ahmed, 1999; Singh and West KP, 2004; Saunders et al., 2004; Ramalho et al., 2002; Semba et al., 2003; Christian, 2002; Resnikoff et al., 1992; Asrat et al., 2002; Haidar and Demissie, 1999; Shaw et al., 2005; Singh and West KP, 2004; Christian, 2002; de Pee et al., 2003; Singh and West KP, 2004; Mele et al., 1991; Al-Kubaisy et al., 2002; Nabakwe et al., 2005; Schaumberg et al., 1996; Ngah et al., 2002; Schemann et al., 2002; Farbos et al., 2000; Maqsood et al., 2004; Singh and West KP, 2004; Taren et al., 2004; Singh and West KP, 2004; Blum et al., 2004; Oso et al., 2003; Rosen et al., 1994; Singh and West KP, 2004; Brink et al., 1979; Wedner et al., 2000; Singh and West KP, 2004; Bloem et al., 1989; Rosen et al., 1996; 
Donnen et al., 1996; Bergen HR et al., 1988; Tielsch et al., 1986) one needs to consider diseases such as Crohn disease (Main et al., 1983; McBain et al., 2005), surgical intervention (McBain et al., 2005; Lee et al., 2005; Purvin, 1999; Parker et al., 1985) including bowl surgery for severe obesity (McBain et al., 2005; Spits et al., 2004) and eating disorders (Velasco Cruz et al., 2005), malabsorption (Perlman et al., 1983), alcohol induced chronic pancreatitis (Ruiz-Martin et al., 2005), cirrhosis (Onder et al., 2005), a mutation to the plasma retinol binding protein (I41N and G75D) (Folli et al., 2005; Bennett et al., 2004), common variable immunodeficiency (Kilic et al., 2005) and pregnancy (Saunders et al., 2004).

VAD can also be observed as a result from acute phase response induced by infection (Nabakwe et al., 2005) in an at risk population (Mihora et al., 2004; Singh and West KP, 2004; Ahmed et al., 2000; Ahmed, 1999; Singh and West KP, 2004; Saunders et al., 2004; Ramalho et al., 2002; Semba et al., 2003; Christian, 2002; Resnikoff et al., 1992; Asrat et al., 2002; Haidar and Demissie, 1999; Shaw et al., 2005; Singh and West KP, 2004; Christian, 2002; de Pee et al., 2003; Singh and West KP, 2004; Mele et al., 1991; Al-Kubaisy et al., 2002; Nabakwe et al., 2005; Schaumberg et al., 1996; Ngah et al., 2002; Schemann et al., 2002; Farbos et al., 2000; Maqsood et al., 2004; Singh and West KP, 2004; Taren et al., 2004; Singh and West KP, 2004; Blum et al., 2004; Oso et al., 2003; Rosen et al., 1994; Singh and West KP, 2004; Brink et al., 1979; Wedner et al., 2000; Singh and West KP, 2004; Bloem et al., 1989; Rosen et al., 1996; Donnen et al., 1996; Bergen HR et al., 1988; Tielsch et al., 1986).

The fundus is normal in early VAD, but may later on show multiple white or grey-white spots in the peripheral retina (Uyemura, 1928), which usually disappear with vitamin A supplementation (McBain et al., 2005; Apushkin 
and Fishman, 2005).

The ERG response shows elevated thresholds for both rods and cones, with the rods being more severely affected (Perlman et al., 1983). In severe cases the rod ERG can be undetectable. The ERG generally normalizes with treatment. McBain and colleagues describe an interesting patient who reported she would see "white as green" and had a selective loss of the S-cone function (McBain et al., 2005). One of the two cases reported by Bennett and colleagues was a photographer by profession and reported that colours appeared as if seen through a yellow filter, the other patient reported that colour appeared as if seen through a red screen (Bennett et al., 2004).

Fluorescein angiography suggests that the white areas in the fundus represent loss of pigment from the retinal pigment epithelium (Sommer, 1982).

The treatment of VAD is straightforward by supplementing vitamin $A$. An interesting new approach using genetically modified rice and maize may may eventually contribute enriching vitamin $A$ in the food, but logistic problems and controversial economical issues need to be addressed (Editorial, 2005). VAD and xeropthalmia were already known to the ancient Egyptians and Greeks who treated it with calf's or goat's liver which have a high vitamin A content (Wolf, 1978) (for a historical review see reference (Wolf, 1996)). However and sadly it needs to be remembered that most of the children affected by VAD will receive treatment too late to make a full recovery.

Melanoma associated retinopathy (MAR) Melanoma associated retinopathy (MAR) belongs to the paraneoplastic syndromes and is characterized 
by the combination of night blindness, phosophenes (the subjective appearance of flickering lights), colour deficits on the tritan axis, reduced visual acuity and central visual field loss occurring in patients with metastatic cutaneous melanoma (Sawyer et al., 1976; Weinstein et al., 1994; Kellner et al., 1995; Jacobson, 1998; Petzold and Plant, 2005; Pfohler et al., 2003; Gass, 1984). Visual symptoms frequently start with night blindness and shimmering, flickering, or pulsating photopsias followed by progressive loss of visual acuity (Keltner et al., 2001). The occurrance of photopsias is very sudden and indicative of loss of vision.

Sawyer was probably the first to recognize in 1976 the relationship between a non-ocular cancer and retinal pathology (Sawyer et al., 1976). Ripps and colleagues were the first to describe the occurrence of night blindness and photopsias in a 30-year old man with melanoma, but they suggested that toxic properties of the chosen chemotherapy (vincristine) were causative (Ripps et al., 1984). Generally Gass is accredited for truly recognizing the MAR syndrome (Gass, 1984).

The mostly accepted pathophysiological mechanism is that (perhaps in an attempt to limit tumour growth) the human immune-system produces antibodies which cross-react with bipolar cells of the retina (Milam et al., 1993; Kellner et al., 1995; Klopfer et al., 1997; Boeck et al., 1997; Weinstein et al., 1994), although this could not be shown in all cases (Fishman et al., 1996; Bret-Dibat et al., 1996; Rougier et al., 1995) and crossreactivity with other retinal cells is also observed (Keltner et al., 2001). One group provided some experimental evidence that the transfer of human IgG from MAR patients into the vitreous of the monkey induces ERG changes also seen in MAR (Lei et al., 2000).

The fundus has been reported as normal in 19 (44\%) of 43 patients. In 
some cases a pale optic disc, attenuation of retinal vessels including retinal periphlebitis, changes of pigmentation, occasional vitreous cells (see Table 6 in reference (Keltner et al., 2001)). The inflammatory changes may be more widespread, involving larger parts of the posterior uvea.

Nyctometry (see Assessment, below) is abnormal in MAR patients (Pfohler et al., 2003). Psychophysical tests suggest a specific M-cell dysfunction with preservation of $\mathrm{P}$-cell function (Arden et al., 1995).

The ERG typically shows a markedly reduced b-wave due to the defunct bipolar cells. A normal A-wave indicates normal functioning of the photoreceptors (Fishman et al., 1996; Barnes et al., 2002). The ERG pattern resembled the one found in CSNB patients in 54 of 56 patients recently reviewed by Keltner and colleagues (see Table 7 in reference (Keltner et al., 2001)).

Treatment of the underlying melanoma is the primary concern to the physician. With regard to the MAR syndrome there are anecdotal reports that corticosteroids, plasmapheresis, intravenous immunoglobulins (IVlg), azathioprine, gabapentin, radiation and cytoreductive surgery may be of some benefit (Guy and Aptsiauri, 1999; Keltner et al., 2001).

Cancer associated retinopathy (CAR) Cancer associated retinopathy (CAR) is another cancer associated paraneoplastic retinal degeneration (Sawyer et al., 1976). CAR can be seen with tumors such as pulmonary small cell carcinoma, breast and other gynecological cancers, endocrine and other malignancies (Keltner et al., 2001).

The main symptoms are loss of visual acuity associated with photopsias which can precede the detection of the cancer by many months. Rod dysfunction is the cause for night blindness, prolonged dark adaptation, 
peripheral and ring scotomata. Cone dysfunction results in photosensitivity, decreased colour vision and visual acuity and central scotomata (Keltner et al., 2001; Petzold and Plant, 2005).

Over 15 different types of antibodies are described with the 23-KDa protein recoverin being the most commonly found antigen, followed by the 46-KDa protein $\alpha$-enolase and others (i.e. neurofilaments, heat shock protein 70, TULP1, etc.) (Keltner and Thirkill, 1998; Adamus et al., 2004; Polans et al., 1995; Thirkill et al., 1992).

The ERG can be abnormal either for cone- or rod-function or for both presumably dependent upon the proteins targeted by the antibodies.

Treatment of the underlying cancer is the main problem.

\section{Autoimmune-related retinopathy and optic neuropathy (ARRON) syn-}

drome Autoimmune-related retinopathy and optic neuropathy (ARRON) syndrome represents a rare and heterogeneous group of patients with retinal degeneration and optic neuropathy thought to be associated to autoimmune antibodies without evidence of cancer, but rather to a systemic autoimmune disease (Keltner et al., 2001). The symptoms frequently resemble those observed in CAR patients. Indeed, antibodies against similar antigens (i.e. recoverin) are found in ARRON and CAR (Keltner et al., 2001; Adamus et al., 2004).

The ERG resembles that seen in CAR patients.

No specific treatment is known and various immunosuppresive strategies have been tried. 


\section{Reduced vision in the mesopic range related to cone dysfunction}

The relevance of cone disease The human retina comprised three types of cones which in their absorption spectra. The S-cones are most sensitive in the short wavelength spectra, the $\mathrm{M}$-cones in the middle wavelength spectra and the L-cones in the long wavelength spectra.

Cone disease may cause problems on first entering dark.

Enhanced S-cone syndrome (ESCS) Enhanced S-cone syndrome (ESCS) is a progressive autosomal receptive disorder which can be caused by a large number of mutations in the NR2ER gene (synonymous to PNR) (Haider et al., 2000) (for review of these mutations see references (Hayashi et al., 2005; Wright et al., 2004)). Marmor et al. coined the term ESCS (Marmor et al., 1990). Inherited retinal dystrophies generally affect the rods and all three cone types (S-cone, M-cones and S-cones). Enhanced S-cone syndrome (ESCS) represents a rare exception because only $\mathrm{M}$ - and $\mathrm{L}-$ cones are affected, whilst the $\mathrm{S}$-cones or blue cones exist in excess (Peng et al., 2005). It has been suggested that NR2ER may be important during retinal development (Bumsted O'Brien et al., 2004; Milam et al., 2002).

Patients with ESCS suffer from night blindness due to rod dysfunction. Most young patients suffer from bilaterally reduced visual acuity (VA) to less than 0.8 , which decreases further with age so that by the age of 20 VA generally decreased to less than 0.4 (Nakamura et al., 2004; Sharon et al., 2003; Nakamura et al., 2002; Yamamoto et al., 1999; Usui et al., 2004). The peripheral VF is reduced and ring scotomata can be observed (Hayashi et al., 2005). Colour vision may or may not be impaired depen- 
dent on severity. The severity and prognosis of ESCS varies from very mild (Hayashi et al., 2005) to severe (Nakamura et al., 2004), dependent on the underlying mutation.

The pathognomic finding in ESCS is the ERG demonstrating "hyperfunction" " of S-cones (Marmor et al., 1990, 2004, 1999; Hood et al., 1995). The diagnosis of ESCS is frequently based on the typical findings in the spectral ERG which combines hypersensitivity to blue stimuli with a hyposensitivity to red stimuli (Hayashi et al., 2005; Marmor et al., 1990). In most patient there is no recordable rod function on ERG, but in very mild form of ESCS the rod ERG showed low rod b-waves (Hayashi et al., 2005).

The fundus findings include cystoid changes in the macula and may also show degenerative changes in the vascular arcade to the mid peripheral retina. Pigmented spots in degenerating areas can also be seen (Nakamura et al., 2002; Hayashi et al., 2005; Jurklies et al., 2001; Marmor et al., 1990).

Optical coherence tomography (OCT) may show large macular retinoschisis and an abnormal laminar retinal architecture (Jacobson et al., 2004; Hayashi and Kitahara, 2005).

Fluorescein (midphase) may reveal hyperfluorescence of the degenerative regions and temporal hypofluorescence in areas where pigmented spots are seen by direct examination of the fundus (Hayashi et al., 2005).

The differential diagnosis of mutations to the NR2E3 gene includes Goldmann-Favre syndrome (Sharon et al., 2003), autosomal recessive retinitis pigmentosa (Gerber et al., 2000), and clumped pigmentary retinal degeneration (Sharon et al., 2003).

\footnotetext{
${ }^{1}$ They are probably not truly hyperactive, but just exist in excess resulting in the stronger electrical response.
} 
Sorsby fundus dystrophy (SFD) Sorsby fundus dystrophy (SFD) represents a rare autosomal dominant macular degeneration, first described by Sorsby and Marson in 1949 (Sorsby and Mason, 1949), which presents with bilateral loss of central vision in the adult. Some patients may present with nyctalopia prior to the development of the maculopathy (Capon et al., 1988; Polkinghorne et al., 1989). Pigment dispersion glaucoma is also observed.

SFD is caused by a mutation on chromosome 22q12-q13 resulting in decreased activity of TIMP3, the inhibitor to the metaloproteinase 3 (MMP3) (Weber et al., 1994). The condition is progressive (Weber et al., 1994).

TIMP3 and MMP3 participate in a complex network of enzymes needed for the normal remodeling of the extracellular matrix (ECM) (Bergers and Coussens, 2000). The degrading activity of MMPs is high and MMPs are tightly controlled by their specific tissue inhibitors (TIMP). A range of disorders has been related to MMPs, but of the TIMPs only TIMP3 has so far been related to disease (Klenotic et al., 2004). In SFD Ser-Cys mutants of TIMP3 accumulate in drusen and in Bruch's membrane similar to what is seen in the more common age-related macular degeneration (AMD) (Tabata et al., 1998; Weber et al., 1994; Kamei and Hollyfield, 1999). The mechanism leading to TIMP3 accumulation remains unknown but is likely to be related to impaired degradation of the protein (Chong et al., 2003).

Fundus examination in the earlier stages show juxtafoveal choroidal neovascularization (Barbazetto et al., 2005), diffuse fine yellowish-white deposits. Retinal hemorrhages may be present (Ayyagari et al., 2000). Later the picture is dominated by retinal and macular atrophy (Figure 5) (Atan et al., 2004). Fluorescein angiography shows the classical features 

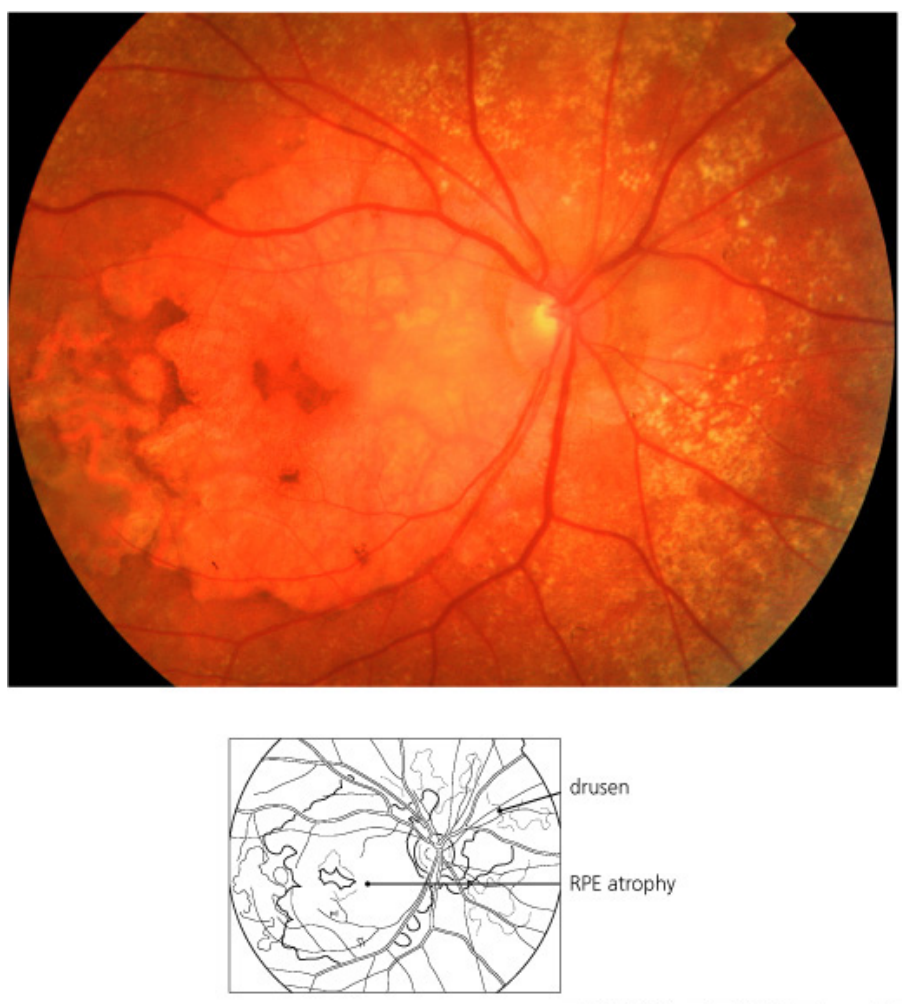
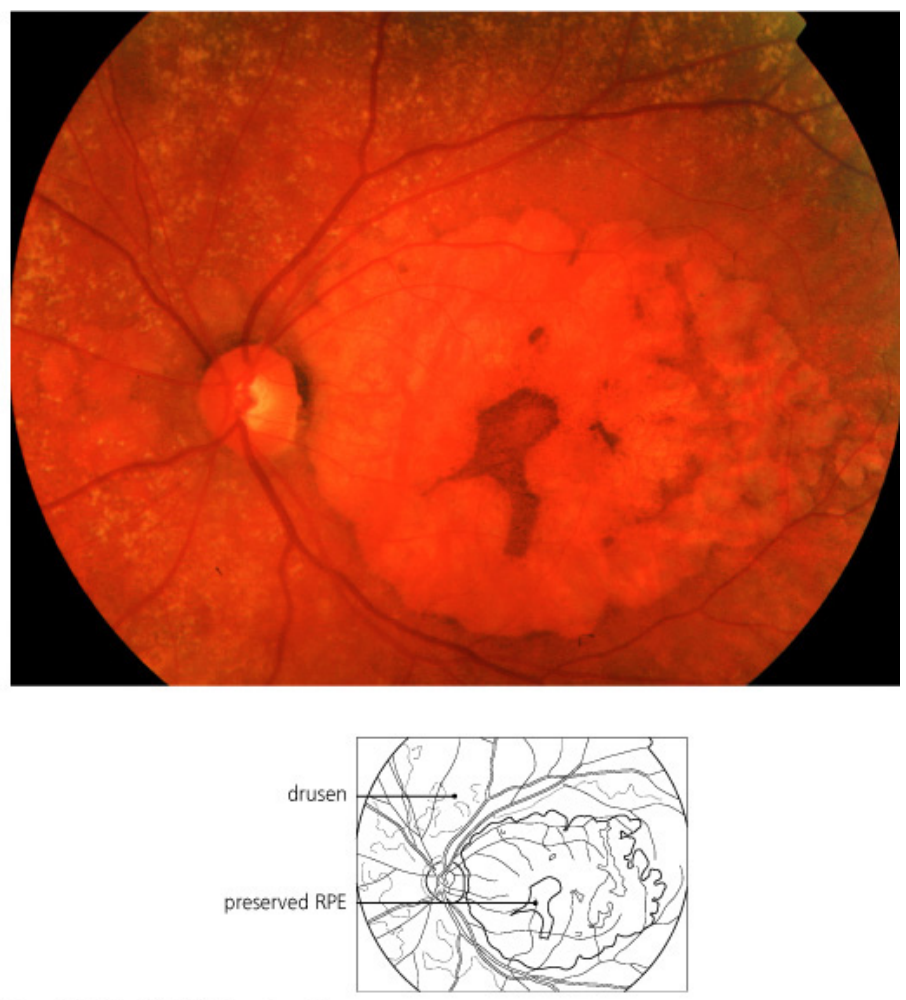

(1) 2005 Elsevier Ltd. Spalton et al: Atlas of Clinical Ophthalmology $3 \mathrm{e}$

Figure 5: Sorsby fundus dystrophy, there is widespread RPE atrophy with an island of RPE preserved centrally. The optic disc is atrophied and the yellowish-white deposits represent drusen. (reproduced with permission from reference (Spalton et al., 2005)).

of choroidal neovascularization, that is to say delayed choroidal filling and retinal pigment epithelial mottling (Barbazetto et al., 2005; Atan et al., 2004).

There is no specific treatment, but retinal neovascularisation may be limited by photodynamic therapy or steroids (Peiretti et al., 2005; Atan et al., 2004). On a very short term basis vitamin A supplement may improve the symptoms (Berson, 2000).

The differential diagnosis includes other conditions with early onset retinal and macular degeneration. 


\section{Assessment}

The most important, easiest and most economical approach is to ask the patient if he/she experiences any problems with his/her night vision. Patients who drive may be particularly aware of impaired vision in the mesopic range. Accurate and reproducible quantification of mesopic vision and changes in mesopic vision over time are very difficult. Discussion of the complexities of mesopic photometry is beyond the scope of this review and the interested reader is referred to the paper by Stockman and Sharpe in this issue. Here we restrict the discussion to some pragmatic assessments which are relevant for assessment of night driving abilities in some countries.

Historically the Nyktometer (Rodenstock) was the probably the most frequently used instrument for assessment of visual acuity under mesopic conditions (Hartmann and Wehmeyer, 1980; Kolling and Schratz, 1991; Schlag, 1993). Several developments have been made and the Mesotest II (Oculus), the Kontrastometer (BKG Medizin Technik GmbH) and the nyktometer 500 (Rodenstock) may currently be the most frequently used aparati (Puell et al., 2004; Schlote et al., 1997; Kolling and Schratz, 1991; , DOG).

The Nyktometer 500 allows for the assessment of monocular and binocular visual acuity under mesopic conditions using Landolt rings (recommended is the use of plate 505). The forehead is rested against a flexible, soft plastic cover which shields the eyes from any stray light. It is possible to keep the spectables on during the test. The aparatus allows to correct for night myopia by adding minus lenses.

The Mesotest I/ is very similar to the Nyktometer. One additional fea- 
ture is that the rear wall of the aparatus can be removed allowing for vision through a half permeable mirror. The idea is that this may allows to avoid night myopia. If this option is used care needs to be taken that the aparatus points towards a non-light reflecting wall and that the illumination in the room is kept constant.

The Kontrastometer again is very similar to the Nyktometer. An advantage of this aparatus is that visual acuity is tested using Landolt rings which are illuminated from behind and also from the side allowing for variation of contrast which is of use for those patients who suffer from very poor mesopic vision. Additionally the Landolt rings can be turned so that the patient cannot memorise the opening position of the ring. The core features of these three aparati are summarized in Table 1. 
Table 1: Characteristics of the Nyktometer 500, Mesotest II and Kontrastometer (adapted from (, DOG)).

\begin{tabular}{llll}
\hline Chasracteristic & Nyktometer 500 & Mesotest II & Kontrastometer \\
\hline Producer & Rodenstock GmbH & Oculus Opticgeräte & BKG Medizin Technik \\
URL & www.rodenstock.com & www.oculus.de & www.bkg-medizintechnik. \\
Optics & binocular & binocular & binocular \\
Field illumination ${\left[\mathrm{cd}^{2}\right]}^{2}$ & $0.032-0.1$ & $0.032-0.1$ & $0.032-0.1$ \\
Stimulus presentation & pre-programmed & choice & random \\
Contrast (range) & plate dependent & \\
Monuclar testing & yes & $2: 1-23: 1$ & $1.14: 1-5: 1$ \\
Correction for night myopia & yes & yes & yes \\
\hline
\end{tabular}

Other tests include the Pelli-Robson letter contrast sensitivity (Wood and Owens, 2005), contrast letters (Pesudovs et al., 2004; Smith RA, 1973) and a new automated test developed by Chisholm and Barbur (Chisholm et al., 2003).

The relationship between mesopic vision and dark-adaptation is of particular importance for divers, pilots, etc. and a number of tests assess this function (Plainis et al., 2005; Babizhayev, 2003; Reiner, 1997). Other visual functions affected by reduced vision in the mesopic range are motion (Takeuchi et al., 2001) and distance judgment (Bourdy et al., 1991).

Electroretinography (ERG) Electroretinography has a central role in the diagnosis of all diseases described in the review. It permits testing of rod function during dark adaptation by providing a white flash of light (scotopic $E R G$ ), cone function adapted to specific light levels (photopic ERG) and both rods and cones if a sufficiently bright light flash is given under dark adaptation (mesopic ERG). At intermediate light levels cone function can be isolated by recording the ERG to rapid flicker or a long wave length stimulus as the rods will not respond to either of these.

The ERG recordings show an initial negative deflection (downwards on the $y$-axis) due to closure of cation channels in the outer segment membrane. This is followed by a positive deflection (upwards on the y-axis) due to activity of the photoreceptors and retinal neurons. In this review we frequently refer to the ERG b-wave which reflects the transmission of the

\footnotetext{
${ }^{2}$ optional see-through field

${ }^{3}$ Three plates are available: 501, 502 and 505 . A potential pitfall with the preprogrammed presentation is that the patient may memorize the stimulus position which causes a problem for repeated measurements.

${ }^{4}$ Plate 501: 1.46:1 - 23:1; plate 502: 1.14:1 - 23:1; plate 505: 2:1 - 23:1.
} 
signal from the photoreceptors to the second-order neurons.

In diseases with predominant or early degeneration of rods, pathological changes in the scotopic ERG precede those of the photopic ERG. Vice versa diseases affecting predominantly the cones mainly change the appearance of the photopic ERG. In cone-rod dystrophy the photopic ERG is affected first, but the scotopic ERG is usually pathological as well. It needs to be remembered that the standard ERG is not sensitive enough to detect diseases limited to the macula with a limited amount of cone loss.

\section{Conclusions}

Impaired vision in the mesopic range is probably the most sensitive and earliest sign of a range of diseases. Frequently taking a history and asking for problems with night vision is sufficient to identify affected patients. Simple tests for assessing mesopic vision have been established and have been recommended as screening tests particularly for VAD which remains the most frequent cause for acquired blindness. More detailed tests of mesopic vision including the nyctometer, ERG, contrast sensitivity, the psychophysics of the dark adaptation and others contribute unraveling the function of the visual pathways and their genetic and molecular biological basis.

It is important to remember that disorders of both the rod and cone systems can affect vision at mesopic levels. However, relatively little is known about how the interactions between the two systems, which only occur at mesopic light levels, can be modified in disease and how this may be manifested in the symptomatology. Even less is known about optic nerve and cerebral disease as in those disorders visual function is almost exclusively studied under photopic conditions. And yet patients with optic nerve disease, for example, will often report that they see better in bright than dim light or vica versa. Patients with bilateral occipital dysfunction may report that their visual world appears abnormally dark, and that "if only there were more light" they would be able to see.

The other articles in this issue, and a growing scientific literature, are evidence of increasing realisation that mesopic vision is also important in everyday life of patients, particularly where driving at night is concerned. In this review we have attempted to provide an understanding of the range of rod and cone system disorders which may result in impaired vision in the mesopic range. In the coming years a greater understanding of the consequences of these and other disorders for mesopic vision will emerge. 


\section{References}

Abramowicz, M., Ribai, P., Cordonnier, M., 2005. Congenital stationary night blindness: report of an autosomal recessive family and linkage analysis. Am J Med Genet A 132, 76-9.

Adamus, G., Ren, G., Weleber, R., 2004. Autoantibodies against retinal proteins in paraneoplastic and autoimmune retinopathy. BMC Ophthalmol 4, 5.

Ahmed, F., 1999. Vitamin A deficiency in Bangladesh: a review and recommendations for improvement. Public Health Nutr 2, 1-14.

Ahmed, F., Rahman, M., Mahmood, C., 2000. Vitamin A deficiency in children with acute diarrhoea: a community-based study in Bangladesh. J Health Popul Nutr 18, 119-22.

Al-Kubaisy, W., Al-Rubaiy, M., Nassief, H., 2002. Xerophthalmia among hospitalized Iraqi children. East Mediterr Health J 8, 496-502.

Allen, L., Zito, I., Bradshaw, K., Patel, R., Bird, A., Fitzke, F., Yates, J., Trump, D., Hardcastle, A., Moore, A., 2003. Genotype-phenotype correlation in British families with X linked congenital stationary night blindness. $\mathrm{Br} J$ Ophthalmol 87, 1413-1420.

Apushkin, M., Fishman, G., 2005. Improvement in visual function and fundus findings for a patient with vitamin A-deficient retinopathy. Retina 25, 650-602.

Arden, G., Wolf, J., Plant, G., 1995. Electrophysiological and psychophysical losses in Cuban optic neuropathy - selective parvocellular damage. Investigative Ophthalmology \& visual science 36, S676-S676.

Asrat, Y., Omwega, A., Muita, J., 2002. Prevalence of vitamin A deficiency among preschool and school-aged children in Arssi Zone, Ethiopia. East Afr Med J 79, 355-309.

Atan, D., Gregory Evans, C., Louis, D., Downes, S., 2004. Sorsby fundus dystrophy presenting with choroidal neovascularisation showing good response to steroid treatment. Br J Ophthalmol 88, 440-401.

Ayyagari, R., Griesinger, I., Bingham, E., Lark, K., Moroi, S., Sieving, P., 2000. Autosomal dominant hemorrhagic macular dystrophy not associated with the TIMP3 gene. Arch Ophthalmol 118, 85-92.

Babizhayev, M., 2003. Glare disability and driving safety. Ophthalmic Res 35, 19-25.

Baillie, I., 1816. Observations on hemeralopia or nightblindness. Medico-Chirugical $\mathrm{J}$ and Review 2, 179-182.

Barbazetto, I., Hayashi, M., Klais, C., Yannuzzi, L., Allikmets, R., 2005. A novel TIMP3 mutation associated with Sorsby fundus dystrophy. Arch Ophthalmol 123, 542-503.

Barnes, C., Alexander, K., Fishman, G., 2002. A distinctive form of congenital stationary night blindness with cone ON-pathway dysfunction. Ophthalmology 109, 575-583. 
Bennett, D., Webster, G., Molyneux, P., Descamps, M., Plant, G., Pereira, S., Reilly, M., 2004. The world through tinted glasses. Lancet 364, 388-300.

Bergen HR, J., Natadisastra, G., Muhilal, H., Dedi, A., Karyadi, D., Olson, J., 1988. Vitamin $A$ and vitamin $E$ status of rural preschool children in West Java, Indonesia, and their response to oral doses of vitamin A and of vitamin E. Am J Clin Nutr 48, 279-285.

Bergers, G., Coussens, L. M., 2000. Extrinsic regulators of epithelial tumor progression: metalloproteinases. Curr. Opin. Genet. Dev. 10, 120-127.

Berson, E., 1996. Retinitis pigmentosa: unfolding its mystery. Proc Natl Acad Sci U S A 93, 4526-4508.

Berson, E., 2000. Nutrition and retinal degenerations. Int Ophthalmol Clin 40, 93-111.

Berson, E., Rosner, B., Sandberg, M., et al., 1993. A randomized trial of vitamin A and vitamin E supplementation for retinitis pigmentosa. Arch Ophthalmol 111, 761-772.

Bloem, M., Wedel, M., Egger, R., Speek, A., Chusilp, K., Saowakontha, S., Schreurs, W., 1989. A prevalence study of vitamin A deficiency and xerophthalmia in northeastern Thailand. Am J Epidemiol 129, 1095-1103.

Blum, L., Pelto, G., Pelto, P., 2004. Coping with a nutrient deficiency: cultural models of vitamin A deficiency in northern Niger. Med Anthropol 23, 195-227.

Boeck, K., Hofmann, S., Klopfer, M., Ian, U., Schmidt, T., Engst, R., Thirkill, C., Ring, J., 1997. Melanoma-associated paraneoplastic retinopathy: case report and review of the literature. $\mathrm{Br} J$ Dermatol 137, 457-460.

Bordley, J., 1908. A family of hemeralopes. Bull. Johns Hopkins Hosp 19, 278-281.

Bourdy, C., Cottin, F., Monot, A., 1991. Errors in distance appreciation and binocular night vision. Ophthalmic Physiol Opt 11, 340-309.

Bradshaw, K., Allen, L., Trump, D., Hardcastle, A., George, N., Moore, A., 2004. A comparison of ERG abnormalities in XLRS and XLCSNB. Doc Ophthalmol 108, 135-45.

Bret-Dibat, C., Rougier, M., Le Rebeller, M., Delaunay, M., 1996. [Melanoma-associated retinopathy. Apropos of a case and review of the literature]. Bull Cancer 83, 10191022.

Brink, E., Perera, W., Broske, S., Cash, R., Smith, J., Sauberlich, H., Bashor, M., 1979. Vitamin A status of children in Sri Lanka. Am J Clin Nutr 32, 84-91.

Brouzas, D., Charakidas, A., Vasilakis, M., Nikakis, P., Chatzoulis, D., 2001. Nyctalopia in antiquity: a review of the ancient Greek, Latin, and Byzantine literature. Ophthalmology 108, 1917-1921.

Bumsted O'Brien, K., Cheng, H., Jiang, Y., Schulte, D., Swaroop, A., Hendrickson, A., 2004. Expression of photoreceptor-specific nuclear receptor NR2E3 in rod photoreceptors of fetal human retina. Invest Ophthalmol Vis Sci 45, 2807-2812. 
Burstedt, M., Forsman-Semb, K., Golovleva, I., Janunger, T., Wachtmeister, L., Sandgren, O., 2001. Ocular phenotype of bothnia dystrophy, an autosomal recessive retinitis pigmentosa associated with an R234W mutation in the RLBP1 gene. Arch Ophthalmol 119, 260-207.

Burstedt, M., Monestam, E., Sandgren, O., 2005. Associations between specific measures of vision and vision-related quality of life in patients with bothnia dystrophy, a defined type of retinitis pigmentosa. Retina 25, 317-323.

Burstedt, M., Sandgren, O., Golovleva, I., Wachtmeister, L., 2003. Retinal function in Bothnia dystrophy. An electrophysiological study. Vision Res 43, 2559-2571.

Burstedt, M., Sandgren, O., Holmgren, G., Forsman-Semb, K., 1999. Bothnia dystrophy caused by mutations in the cellular retinaldehyde-binding protein gene (RLBP1) on chromosome 15q26. Invest Ophthalmol Vis Sci 40, 995-1000.

Capon, M., Polkinghorne, P., Fitzke, F., Bird, A., 1988. Sorsby's pseudoinflammatory macular dystrophy: Sorsby's fundus dystrophies. Eye 2, 114-122.

Carr, R., Ripps, H., 1967. Rhodopsin kinetics and rod adaptation in Oguchi's disease. Invest. Ophthalmol. Vis. Sci. 6, 426-436.

Carr, R., Ripps, H., Siegel, I., 1974. Rhodopsin kinetics and rod adaptation in fundus albipunctatus. Doc Ophthalmol Proc Ser 4, $193 a ̂ 204$.

Chisholm, C., Evans, A., Harlow, J., Barbur, J., 2003. New test to assess pilot's vision following refractive surgery. Aviat Space Environ Med 74, 551-509.

Chong, N., Kvanta, A., Seregard, S., Bird, A., Luthert, P., Steen, B., 2003. TIMP-3 mRNA is not overexpressed in Sorsby fundus dystrophy. Am J Ophthalmol 136, 954-905.

Christian, P., 2002. Recommendations for indicators: night blindness during pregnancy-a simple tool to assess vitamin A deficiency in a population. J Nutr 132, 2884S-2888S.

Cideciyan, A., Haeseleer, F., Fariss, R., Aleman, T., Jang, G., Verlinde, C., Marmor, M., Jacobson, S., Palczewski, K., 2000. Rod and cone visual cycle consequences of a null mutation in the 11-cis-retinol dehydrogenase gene in man. Vis Neurosci 17, 667-678.

Cideciyan, A., Zhao, X., Nielsen, L., Khani, S., Jacobson, S., Palczewski, K., 1998. Null mutation in the rhodopsin kinase gene slows recovery kinetics of rod and cone phototransduction in man. Proc. Natl. Acad. Sci. USA 95, 328-333.

Cunier, F., 1838. Histoire d'une hemeralopie hereditaire depuis deux siecles dans une famille de la commune de Vendemian pres de Montpelier. Ann Soc Med Gand 4, 385395.

de Pee, S., Bloem, M., Kiess, L., Panagides, D., Talukder, A., 2003. Integrating strategies for combating vitamin A deficiency: successes in Asia. Forum Nutr 56, 210-202.

Delyfer, M., Leveillard, T., Mohand-Said, S., Hicks, D., Picaud, S., Sahel, J., 2004. Inherited retinal degenerations: therapeutic prospects. Biol Cell 96, 261-209. 
(DOG), D. O. G., 2003. Empfehlungen der Deutschen Ophthalmologischen Gesellschaft zur Qualitätssicherung bei sinnesphysiologischen Untersuchungen und Geräten. http://www.dog.org/publikationen-sinnesphysiologie/vorwort.html.

Donnen, P., Brasseur, D., Dramaix, M., Vertongen, F., Ngoy, B., Zihindula, M., Hennart, P., 1996. Vitamin A deficiency and protein-energy malnutrition in a sample of pre-school age children in the Kivu Province in Zaire. Eur J Clin Nutr 50, 456-461.

Dryja, T., 2000. Molecular genetics of Oguchi disease, fundus albipunctatus, and other forms of stationary night blindness: LVII Edward Jackson Memorial Lecture. Am J Ophthalmol 130, 547-563.

Duke-Elder, S., 1963. System of Ophthalmology, Normal and Abnormal Development. C. V. Mosby, St. Louis.

Editorial, A., 2005. Reburnishing golden rice. Nat Biotechnol 23, 395.

Eichers, E., Green, J., Stockton, D., Jackman, C., Whelan, J., McNamara, J., Johnson, G., Lupski, J., Katsanis, N., 2002. Newfoundland rod-cone dystrophy, an early-onset retinal dystrophy, is caused by splice-junction mutations in RLBP1. Am J Hum Genet 70, 955-964.

Farbos, S., Resnikoff, S., Peyramaure, F., 2000. Urbanisation and vitamin A deficiency in children: comparison between a traditional district and a new settlement in Mali. Eur $\mathrm{J}$ Epidemiol 16, 1143-1109.

Fishman, G., Alexander, K., Milam, A., Derlacki, D., 1996. Acquired unilateral night blindness associated with a negative electroretinogram waveform. Ophthalmology 103, 96104.

Fishman, G., Roberts, M., Derlacki, D., Grimsby, J., Yamamoto, H., Sharon, D., Nishiguchi, K., Dryja, T., 2004. Novel mutations in the cellular retinaldehyde-binding protein gene (RLBP1) associated with retinitis punctata albescens: evidence of interfamilial genetic heterogeneity and fundus changes in heterozygotes. Arch Ophthalmol $122,70-5$.

Folli, C., Viglione, S., Busconi, M., Berni, R., 2005. Biochemical basis for retinol deficiency induced by the $141 \mathrm{~N}$ and G75D mutations in human plasma retinol-binding protein. Biochem Biophys Res Commun 336, 1017-1022.

Fuch, A., 1959. White spots of the fundus combined with night blindness and xerosis (Uyemura's syndrome). Am J Ophthalmol 48, 101-3.

Fuchs, A., 1928. Ein Fall von weisspunktiertem Fundus bei Hemeralopie mit Xerose. Klin Monatsbl Augenheilkd 81, 849-850.

Gass, J., 1984. Uveitis Update. Proceedings of the International Symposium on UveitisHanasaari in Espoo, Finland. Elsevier Science Publishers, Amsterdam, Ch. Acute Vogt-Koyanagi-Harada-like syndrome occurring in a patient with metastatic cutaneous melanoma, pp. 407-408. 
Gerber, S., Rozet, J., Takezawa, S., et al., 2000. The photoreceptor cell-specific nuclear receptor gene (PNR) accounts for retinitis pigmentosa in the Crypto-Jews from Portugal (Marranos), survivors from the Spanish Inquisition. Hum Genet 107, $276 a ̂ 284$.

Granse, L., Abrahamson, M., Ponjavic, V., Andreasson, S., 2001. Electrophysiological findings in two young patients with Bothnia dystrophy and a mutation in the RLBP1 gene. Ophthalmic Genet 22, 97-105.

Gross-Jendroska, M., Schatz, H., McDonald, H., Johnson, R., 1992. Kearns-Sayre syndrome: a case report and review. Eur J Ophthalmol 2, 15-20.

Guy, J., Aptsiauri, N., 1999. Treatment of paraneoplastic visual loss with intravenous immunoglobulin: report of 3 cases. Arch Ophthalmol 117, 471-407.

Haidar, J., Demissie, T., 1999. Malnutrition and xerophthalmia in rural communities of Ethiopia. East Afr Med J 76, 590-503.

Haider, N., Jacobson, S., Cideciyan, A., Swiderski, R., Streb, L., Searby, C., Beck, G., Hockey, R., Hanna, D., Gorman, S., Duhl, D., Carmi, R., Bennett, J., Weleber, R., Fishman, G., Wright, A., Stone, E., Sheffield, V., 2000. Mutation of a nuclear receptor gene, NR2E3, causes enhanced $S$ cone syndrome, a disorder of retinal cell fate. Nat Genet 24, 127-31.

Hartmann, E., Wehmeyer, K., 1980. [Investigation of mesopic vision and sensitivity to glare by means of the new "nyktometer" (author's transl)]. Klin Monatsbl Augenheilkd $176,859-863$.

Hayashi, T., Gekka, T., Goto-Omoto, S., Takeuchi, T., Kubo, A., Kitahara, K., 2005. Novel NR2E3 mutations (R104Q, R334G) associated with a mild form of enhanced S-cone syndrome demonstrate compound heterozygosity. Ophthalmology 112, 2115-2100.

Hayashi, T., Kitahara, K., 2005. Optical coherence tomography in enhanced S-cone syndrome: large macular retinoschisis with disorganized retinal lamination. Eur J Ophthalmol 15, 643-606.

Heckenlively, J., 1988. Retinitis Pigmentosa. J.B. Lippincott Co., Philadelphia.

Hims, M., Diager, S., Inglehearn, C., 2003. Retinitis pigmentosa: genes, proteins and prospects. Dev Ophthalmol 37, 109-25.

Hood, D., Cideciyan, A., Roman, A., Jacobson, S., 1995. Enhanced S cone syndrome: evidence for an abnormally large number of $S$ cones. Vision Res 35, 1473-1481.

Jacobson, D., 1998. Walsh \& Hoyt's Clinical Neuro-ophthalmology. Williams \& Wilkins, Baltimore, Ch. Paraneoplastic diseases of neuro-ophthalmology interest, pp. 24972551.

Jacobson, S., Sumaroka, A., Aleman, T., Cideciyan, A., Schwartz, S., Roman, A., Mclnnes, R., Sheffield, V., Stone, E., Swaroop, A., AF, W., 2004. Nuclear receptor NR2E3 gene mutations distort human retinal laminar architecture and cause an unusual degeneration. Hum Mol Genet 13, 1893-1902. 
JP, W., 2001. Florent Cunier [1812-1852]. A tragic figure in ophthalmic history. Strabismus 9, 177-8.

Jurklies, B., Weismann, M., Kellner, U., Zrenner, E., Bornfeld, N., 2001. [Clinical findings in autosomal recessive syndrome of blue cone hypersensitivity]. Ophthalmologe 98, 285-293.

Kabanarou, S. A., Holder, G. E., Fitzke, F. W., Bird, A. C., Webster, A. R., Aug 2004. Congenital stationary night blindness and a "schubert-bornschein" type electrophysiology in a family with dominant inheritance. $\mathrm{Br} \mathrm{J}$ Ophthalmol 88 (8), 1018-1022.

URL http://dx.doi.org/10.1136/bjo.2003.033555

Kalloniatis, M., Fletcher, E., 2004. Retinitis pigmentosa: understanding the clinical presentation, mechanisms and treatment options. Clin Exp Optom 87, 65-80.

Kamei, M., Hollyfield, J., 1999. TIMP-3 in Bruch's Membrane: Changes during Aging and in Age-Related Macular Degeneration. Investig. Ophthalmol. Vis. Sci. 40, 2367-2375.

Kellner, U., Bornfeld, N., Foerster, M., 1995. Severe course of cutaneous melanoma associated paraneoplastic retinopathy. Br J Ophthalmol 79, 746-752.

Keltner, J., Thirkill, C., 1998. Cancer-associated retinopathy vs recoverin-associated retinopathy. Am J Ophthalmol 126, 296-302, [editorial] [published erratum appears in Am J Ophthalmol 1998;126:866].

Keltner, J., Thirkill, C., Yip, P., 2001. Clinical and immunologic characteristics of melanoma-associated retinopathy syndrome: eleven new cases and a review of 51 previously published cases. J Neuroophthalmol 21, 173-87.

Kilic, S., Kezer, E., IIcol, Y., Yakut, T., Aydin, S., Ulus, I., 2005. Vitamin a deficiency in patients with common variable immunodeficiency. J Clin Immunol 25, 275-280.

Klenotic, P., Munier, F., Marmorstein, L., Anand-Apte, B., 2004. Tissue inhibitor of metalloproteinases-3 (TIMP-3) is a binding partner of epithelial growth factorcontaining fibulin-like extracellular matrix protein 1 (EFEMP1). Implications for macular degenerations. J Biol Chem 279, 30469-30473.

Klopfer, M., Schmidt, T., Leipert, K., Ugi, I., Boeck, K., Hofmann, S., 1997. [Melanomaassociated retinopathy with night blindness. Case report]. Ophthalmologe 94, 563507.

Kolling, G., Schratz, B., 1991. [Comparative studies of twilight vision with the Mesoptometer I and II and the Nyktometer]. Fortschr Ophthalmol 88, 178-81.

Lamb, T., Pugh EN, J., 2004. Dark adaptation and the retinoid cycle of vision. Prog Retin Eye Res 23, 307-380.

Langrova, H., Gamer, D., Friedburg, C., Besch, D., Zrenner, E., Apfelstedt-Sylla, E., 2002. Abnormalities of the long flash ERG in congenital stationary night blindness of the Schubert-Bornschein type. Vision Res 42, 1475-1483. 
Lauber, H., 1910. Die sogenannte retinitis punctata albescens. Klin Monatsbl Augenheilkd 48, 133-148.

Lee, W., Hamilton, S., Harris, J., Schwab, I., 2005. Ocular complications of hypovitaminosis a after bariatric surgery. Ophthalmology 112, 1031-1004.

Lei, B., Bush, R., Milam, A., Sieving, P., 2000. Human melanoma-associated retinopathy (MAR) antibodies alter the retinal ON-response of the monkey ERG in vivo. Invest Ophthalmol Vis Sci 41, 262-206.

Lorenz, B., Andrassi, M., Miliczek, K., 1996. [Incomplete congenital stationary night blindness (CSNB). An important differential diagnosis of congenital nystagmus]. Klin Monatsbl Augenheilkd 208, 48-55.

Main, A., Mills, P., Russell, R., Bronte-Stewart, J., Nelson, L., McLelland, A., Shenkin, A., 1983. Vitamin A deficiency in Crohn's disease. Gut 24, 1169-1175.

Manabe, Y., Narai, H., Warita, H., Hayashi, T., Shiro, Y., Sakai, K., Kashihara, K., Shoji, M., Abe, K., 2002. Benign adult familial myoclonic epilepsy (BAFME) with night blindness. Seizure 11, 266-268.

Mansergh, F., Orton, N., Vessey, J., Lalonde, M., Stell, W., Tremblay, F., Barnes, S., Rancourt, D., Bech-Hansen, N., 2005. Mutation of the calcium channel gene Cacna1f disrupts calcium signaling, synaptic transmission and cellular organization in mouse retina. Hum Mol Genet 14, 3035-3046.

Maqsood, M., Dancheck, B., Gamble, M., Palafox, N., Ricks, M., Briand, K., Semba, R., 2004. Vitamin A deficiency and inflammatory markers among preschool children in the Republic of the Marshall Islands. Nutr J 3, 21.

Marmor, M., Cabael, L., Shukla, S., Hwang, J., Marcus, M., 2004. Clinical S-cone ERG recording with a commercial hand-held full-field stimulator. Doc Ophthalmol 109, 1017.

Marmor, M., Jacobson, S., Foerster, M., Kellner, U., Weleber, R., 1990. Diagnostic clinical findings of a new syndrome with night blindness, maculopathy, and enhanced $S$ cone sensitivity. Am J Ophthalmol 110, 124-34.

Marmor, M., Tan, F., Sutter, E., Bearse MA, J., 1999. Topography of cone electrophysiology in the enhanced S cone syndrome. Invest Ophthalmol Vis Sci 40, 1866-1873.

Marmor, M., Zrenner, E., 1998-99. Standard for clinical electroretinography (1999 update). International Society for Clinical Electrophysiology of Vision. Doc Ophthalmol $97,143-56$

Maw, M., Kennedy, B., Knight, A., Bridges, R., Roth, K., Mani, E., Mukkadan, J., Nancarrow, D., Crabb, J., Denton, M., 1997. Mutation of the gene encoding cellular retinaldehyde-binding protein in autosomal recessive retinitis pigmentosa. Nat Genet 17, 198-200. 
McBain, V., Egan, C., Pieris, S., Supramaniam, G., Webster, A., Bird, A., Holder, G., 2005. Functional observations in vitamin A deficiency: diagnosis and time course of recovery. EyeDec 9; [Epub ahead of print].

Mele, L., West KP, J., , K., Pandji, A., Nendrawati, H., Tilden, R., Tarwotjo, I., 1991. Nutritional and household risk factors for xerophthalmia in Aceh, Indonesia: a casecontrol study. The Aceh Study Group. Am J Clin Nutr 53, 1460-1405.

Mihora, L., Jatla, K., Little, T., Campbell, M., Rahim, A., Enzenauer, R., 2004. Vitamin A deficiency in Afghanistan. Eye Contact Lens 30, 159-62.

Milam, A., Rose, L., Cideciyan, A., Barakat, M., Tang, W., Gupta, N., Aleman, T., Wright, A., Stone, E., Sheffield, V., Jacobson, S., 2002. The nuclear receptor NR2E3 plays a role in human retinal photoreceptor differentiation and degeneration. Proc Natl Acad Sci U S A 99, 473-408.

Milam, A., Saari, J., Jacobson, S., Lubinski, W., Feun, L., Alexander, K., 1993. Autoantibodies against retinal bipolar cells in cutaneous melanoma-associated retinopathy. Invest Ophthalmol Vis Sci 34, 91-100.

Miyake, Y., Horiguchi, M., Suzuki, S., Kondo, M., Tanikawa, A., 1996. Electrophysiological findings in patients with Oguchi's disease. Jpn J Ophthalmol 40, 511-509.

Miyake, Y., Horiguchi, M., Terasaki, H., Kondo, M., 1994. Scotopic threshold response in complete and incomplete types of congenital stationary night blindness. Invest Ophthalmol Vis Sci 35, 3770-3705.

Miyake, Y., Yagasaki, K., Horiguchi, M., et al., 1986. Congenital stationary night blindness with negative electroretinogram: a new classification. Arch Ophthalmol, 1013-1020.

Mizuo, A., 1913. A new discovery on dark adaptation in Oguchi's disease. Acta Soc. Ophthalmol. Jpn. 17, 1148â1150.

Morimura, H., Berson, E., Dryja, T., 1999. Recessive mutations in the RLBP1 gene encoding cellular retinaldehyde-binding protein in a form of retinitis punctata albescens. Invest Ophthalmol Vis Sci 40, 1000-1004.

Muradov, K., Granovsky, A., Artemyev, N., 2003. Mutation in rod PDE6 linked to congenital stationary night blindness impairs the enzyme inhibition by its gamma-subunit. Biochemistry 42, 3305-3310.

Nabakwe, E., Lichtenbelt, W., Ngare, D., Wierik, M., Westerterp, K., Owino, O., 2005. Vitamin a deficiency and anaemia in young children living in a malaria endemic district of western Kenya. East Afr Med J 82, 300-306.

Nakamura, M., Hotta, Y., Piao, C., Kondo, M., Terasaki, H., Miyake, Y., 2002. Enhanced S-cone syndrome with subfoveal neovascularization. Am J Ophthalmol 133, 575-507.

Nakamura, M., Lin, J., Ito, Y., Miyake, Y., 2005. Novel mutation in RLBP1 gene in a Japanese patient with retinitis punctata albescens. Am J Ophthalmol 139, 1133-1105. 
Nakamura, M., Miyake, Y., 2002. Macular dystrophy in a 9-year-old boy with fundus albipunctatus. Am J Ophthalmol 133, 278-280.

Nakamura, M., Skalet, J., Miyake, Y., 2003. RDH5 gene mutations and electroretinogram in fundus albipunctatus with or without macular dystrophy: RDH5 mutations and ERG in fundus albipunctatus. Doc Ophthalmol 107, 3-11.

Nakamura, Y., Hayashi, T., Kozaki, K., Kubo, A., Omoto, S., Watanabe, A., Toda, K., Takeuchi, T., Gekka, T., Kitahara, K., 2004. Enhanced S-cone syndrome in a Japanese family with a nonsense NR2E3 mutation (Q350X). Acta Ophthalmol Scand 82, 616622.

Nettleship, E., 1907. A history of congenital stationary night-blindness in nine consecutive generations. Trans. Ophthal. Soc. U.K 27, 269-293.

Ngah, N., Moktar, N., Isa, N., Selvara, S., Yusof, M., Sani, H., Hasan, Z., Kadir, R., 2002. Ocular manifestation of vitamin A deficiency among Orang asli (Aborigine) children in Malaysia. Asia Pac J Clin Nutr 11, 88-91.

Niwa, Y., Kondo, M., Ueno, S., Nakamura, M., Terasaki, H., Miyake, Y., 2005. Cone and rod dysfunction in fundus albipunctatus with RDH5 mutation: an electrophysiological study. Invest Ophthalmol Vis Sci 46, 1480-1405.

Oguchi, C., 1912. Ueber die eigenartige Hemeralopie mit diffuser weissgraeulicher Verfaerbung des Augenhintergrundes. Graeffe Arch. Ophthalmol. 81, 109-117.

Onder, C., Bengur, T., Selcuk, D., Bulent, S., Belkis, U., Ahmet, M., Eser, P., Leyla, A., 2005. Relationship between retinopathy and cirrhosis. World J Gastroenterol 11, 2193-2106.

Oso, O., Abiodun, P., Omotade, O., Oyewole, D., 2003. Vitamin A status and nutritional intake of carotenoids of preschool children in ljaye Orile community in Nigeria. J Trop Pediatr 49, 42-7.

Pagon, R., 1988. Retinitis pigmentosa. Surv Ophthalmol 33, 137-77.

Parker, W., Clorfeine, G., Longstreth, G., 1985. Night blindness after jejunoileal bypass surgery. Am J Gastroenterol 80, 535-507.

Peiretti, E., Klancnik JM, J., Spaide, R., Yannuzzi, L., 2005. Choroidal neovascularization in sorsby fundus dystrophy treated with photodynamic therapy and intravitreal triamcinolone acetonide. Retina 25, 377-309.

Peng, G., Ahmad, O., Ahmad, F., Liu, J., Chen, S., 2005. The photoreceptor-specific nuclear receptor $\mathrm{Nr} 2 \mathrm{e} 3$ interacts with $\mathrm{Crx}$ and exerts opposing effects on the transcription of rod versus cone genes. Hum Mol Genet 14, 747-764.

Perlman, I., Barzilai, D., Haim, T., Schramek, A., 1983. Night vision in a case of vitamin A deficiency due to malabsorption. $\mathrm{Br} \mathrm{J}$ Ophthalmol 67, 37-42. 
Pesudovs, K., Marsack, J., Donnelly WJ, r., Thibos, L., Applegate, R., 2004. Measuring visual acuity-mesopic or photopic conditions, and high or low contrast letters? J Refract Surg 20, S508-14.

Petzold, A., Plant, G., 2005. Central and paracentral visual field defects and driving abilities. Ophthalmologica 219, 191-201.

Pfohler, C., Haus, A., Palmowski, A., Ugurel, S., Ruprecht, K., Thirkill, C., Tilgen, W., Reinhold, U., 2003. Melanoma-associated retinopathy: high frequency of subclinical findings in patients with melanoma. Br J Dermatol 149, 74-8.

Phelan, J., Bok, D., 2000. A brief review of retinitis pigmentosa and the identified retinitis pigmentosa genes. Mol Vis 6, 116-24.

Plainis, S., Murray, I., Charman, W., 2005. The role of retinal adaptation in night driving. Optom Vis Sci 82, 682-608.

Polans, A., Witkowska, D., Haley, T., Amundson, D., Baizer, L., Adamus, G., 1995. Recoverin, a photoreceptor-specific calcium-binding protein, is expressed by the tumor of a patient with cancer-associated retinopathy. Proc Natl Acad Sci U S A 92, 9176-9180.

Polkinghorne, P., Capon, M., Berninger, T., Lyness, A., Sehmi, K., Bird, A., 1989. Sorsby's fundus dystrophy: a clinical study. Ophthalmology 96, 1763-1768.

Puell, M., Palomo, C., Sanchez-Ramos, C., Villena, C., 2004. Mesopic contrast sensitivity in the presence or absence of glare in a large driver population. Graefes Arch Clin Exp Ophthalmol 242, 755-761.

Purvin, V., 1999. Through a shade darkly. Surv Ophthalmol 43, 335-340.

Ramalho, R., Flores, H., Saunders, C., 2002. [Hypovitaminosis A in Brazil: a public health problem]. Rev Panam Salud Publica 12, 117-22.

Reiner, J., 1997. [Dark adaptation for evaluating visual performance at twilight using the Trendelenburg eyeglasses]. Klin Monatsbl Augenheilkd 210, 111-102.

Resnikoff, S., Filliard, G., Carlier, C., Luzeau, R., Amedee-Manesme, O., 1992. Assessment of vitamin A deficiency in the Republic of Djibouti. Eur J Clin Nutr 46, 25-30.

Ripps, H., Carr, R., Siegel, I., Greenstein, V., 1984. Functional abnormalities in vincristine-induced night blindness. Invest Ophthalmol 25, 787-794.

Rolling, F., 2004. Recombinant AAV-mediated gene transfer to the retina: gene therapy perspectives. Gene Ther 11 Suppl 1, S26-32.

Rosen, D., al Sharif, Z., Bashir, M., al Shabooti, A., Pizzarello, L., 1996. Vitamin A deficiency and xerophthalmia in western Yemen. Eur J Clin Nutr 50, 54-7.

Rosen, D., Sloan, N., del Rosario, A., de la Paz, T., 1994. Risk factors for vitamin A deficiency in rural areas of the Philippines. J Trop Pediatr 40, 82-7. 
Rougier, M., Hostyn, P., Bret-Dibat, C., Delaunay, M., Riss, I., Le Rebeller, M., 1995. [Paraneoplastic retinopathy associated with cutaneous melanoma. An update apropos of a case]. J Fr Ophtalmol 18, 396-403.

Ruiz-Martin, M., Boto-de Los-Bueis, A., Romero-Martin, R., 2005. [Severe bilateral ocular affection caused by vitamin A deficiency.]. Arch Soc Esp Oftalmol 80, 663-606.

Saunders, C., do Carmo Leal, M., Gomes, M., Campos, L., dos Santos Silva, B., Thiapo de Lima, A., Ramalho, R., 2004. Gestational nightblindness among women attending a public maternity hospital in Rio de Janeiro, Brazil. J Health Popul Nutr 22, 348-356.

Sawyer, R., Selhorst, J., Zimmerman, L., Hoyt, W., 1976. Blindness caused by photoreceptor degeneration as a remote effect of cancer. Am J Ophthalmol 81, 606-613.

Schaumberg, D., O'Connor, J., Semba, R., 1996. Risk factors for xerophthalmia in the Republic of Kiribati. Eur J Clin Nutr 50, 761-704.

Schemann, J., Banou, A., Guindo, A., Joret, V., Traore, L., Malvy, D., 2002. Prevalence of undernutrition and vitamin A deficiency in the Dogon Region, Mali. J Am Coll Nutr 21, 381-307.

Schlag, B., 1993. Elderly drivers in Germany-fitness and driving behavior. Accid Anal Prev 25, 47-55.

Schlote, T., Kriegerowski, M., Bende, T., Derse, M., Thiel, H., Jean, B., 1997. Mesopic vision in myopia corrected by photorefractive keratectomy, soft contact lenses, and spectacles. J Cataract Refract Surg 23, 718-725.

Schubert, G., Bornschein, H., 1952. Beitrag zur Analyse des menschlichen Electroretinogram. Ophthalmologica 123, 396-413.

Semba, R., de Pee, S., Panagides, D., Poly, O., Bloem, M., 2003. Risk factors for nightblindness among women of childbearing age in Cambodia. Eur J Clin Nutr 57, 16271632.

Sharon, D., Sandberg, M., Caruso, R., Berson, E., Dryja, T., 2003. Shared mutations in NR2E3 in enhanced S-cone syndrome, Goldmann-Favre syndrome, and many cases of clumped pigmentary retinal degeneration. Arch Ophthalmol 121, 1316-1323.

Sharp, D., Arden, G., Kemp, C., Hogg, C., Bird, A., 1990. Mechanisms and sites of loss of scotopic sensitivity: a clinical analysis of congenital stationary night blindness. Clin. Vision Sci. 5, 217-230.

Shaw, C., Islam, M., Chakroborty, M., Biswas, M., Ghosh, T., Biswas, G., 2005. Xerophthalmia: a study among malnourished children of West Mednipur District. J Indian Med Assoc 103, 180, 182-103.

Singh, V., West KP, J., 2004. Vitamin A deficiency and xerophthalmia among school-aged children in Southeastern Asia. Eur J Clin Nutr 58, 1342-1309. 
Skinner, H., 1970. The Origin of Medical Terms, 2nd Edition. Hafner Publishing Co, New York.

Smith RA, J., 1973. Luminance-dependent changes in mesopic visual contrast sensitivity. J Physiol 230, 115-35.

Sommer, A., 1982. Nutritional blindness: Xerophthalmia and Keratomalacia. Oxford Univ. Press., New York.

Sorsby, A., Mason, M., 1949. A fundus dystrophy with unusual features. $\mathrm{Br} \mathrm{J}$ Ophthalmol. 33, 67-97.

Souied, E., Soubrane, G., Benlian, P., Coscas, G., Gerber, S., Munnich, A., Kaplan, J., 1996. Retinitis punctata albescens associated with the Arg135Trp mutation in the rhodopsin gene. Am J Ophthalmol 121, 19-25.

Spalton, D., Hitchings, R., Hunter, P., 2005. Atlas of clinical ophthalmology, 3rd Edition. Elsevier Mosby.

Spits, Y., De Laey, J., Leroy, B., 2004. Rapid recovery of night blindness due to obesity surgery after vitamin A repletion therapy. Br J Ophthalmol 88, 583-505.

Stephenson, S., 1896. On epithehal xerosis of the conjunctiva. Trans Ophthalmol Soc UK $18,55-102$.

Tabata, Y., Isashiki, Y., Kamimura, K., Nakao, K., Ohba, N., 1998. A novel splice site mutation in the tissue inhibitor of the metalloproteinases-3 gene in Sorsby's fundus dystrophy with unusual clinical features. Hum Genet 103, 179-82.

Takeuchi, T., De Valois, K., Motoyoshi, I., 2001. Light adaptation in motion direction judgments. J Opt Soc Am A Opt Image Sci Vis 18, 755-764.

Taren, D., Duncan, B., Shrestha, K., Shrestha, N., Genaro-Wolf, D., Schleicher, R., Pfeiffer, C., Sowell, A., Greivenkamp, J., Canfield, L., 2004. The night vision threshold test is a better predictor of low serum vitamin A concentration than self-reported night blindness in pregnant urban Nepalese women. J Nutr 134, 2573-2508.

Thirkill, C., Tait, R., Tyler, N., Roth, A., Keltner, J., 1992. The cancer-associated retinopathy antigen is a recoverin-like protein. Invest Ophthalmol Vis Sci 33, 2768-2772.

Tielsch, J., Sommer, a., 1984. The epidemiology of vitamin A deficiency and xerophthalmia. Ann Rev Nutr 4, 183-205.

Tielsch, J., West KP, J., Katz, J., Chirambo, M., Schwab, L., Johnson, G., Tizazu, T., Swartwood, J., Sommer, A., 1986. Prevalence and severity of xerophthalmia in southern Malawi. Am J Epidemiol 124, 561-508.

Underwood, B., 2004. Vitamin A deficiency disorders: international efforts to control a preventable pox. J Nutr 134, 231S-236S. 
Usui, T., Ichibe, M., Tanimoto, N., Ueki, S., Takagi, M., Hasegawa, S., Abe, H., Miyagawa, Y., Nakazawa, M., 2004. Ocular fundus images by scanning laser ophthalmoscopy in a patient with enhanced S-cone syndrome. Retina 24, 946-952.

Uyemura, M., 1928. Ueber eine merkwurdige Augenhintergrundveraenerung bei zwei Faellen von idiopathischer Hemerlopie. Klin Monatsbl Augenheilkd 81, 471-473.

Velasco Cruz, A., Attie-Castro, F., Fernandes, S., Cortes, J., de Tarso P Pierre-Filho, P., Rocha, E., Marchini, J., 2005. Adult blindness secondary to vitamin A deficiency associated with an eating disorder. Nutrition 21, 630-603.

Weber, B., Vogt, G., Pruett, R., Stohr, H., Felbor, U., 1994. Mutations in the tissue inhibitor of metalloproteinases-3 (TIMP3) in patients with Sorsby's fundus dystrophy. Nat Genet 8, 352-306.

Wedner, S., Ross, D., Balira, R., Kaji, L., Foster, A., 2000. Prevalence of eye diseases in primary school children in a rural area of Tanzania. Br J Ophthalmol 84, 1291-1207.

Weinstein, J., Kelman, S., Bresnick, G., Kornguth, S., 1994. Paraneoplastic retinopathy associated with antiretinal bipolar cell antibodies in cutaneous malignant melanoma. Ophthalmology 101, 1236-1243.

Weiss, J., Rodrigues, M., Kruth, H., Rajagopalan, S., Rader, D., Kachadoorian, H., 1992. Panstromal Schnyder's corneal dystrophy. Ultrastructural and histochemical studies. Ophthalmology 99, 1072-1081.

Weiss, N., 1991. Low vision management of retinitis pigmentosa. J Am Optom Assoc 62, 42-52.

Weleber, R., 1994. Retina, 2nd Edition. Mosby, Ch. Retinitis pigmentosa and allied disorders, pp. 335-466.

Weleber, R., 2002. Infantile and childhood retinal blindness: a molecular perspective (The Franceschetti Lecture). Ophthalmic Genet 23, 71-97.

Wolf, G., 1978. A historical note on the mode of administration of vitamin A for the cure of night blindness. Am J Clin Nutr 31, 290-292.

Wolf, G., 1996. A history of vitamin A and retinoids. FASEB 10, 1102-1107.

Wood, J., Owens, D., 2005. Standard measures of visual acuity do not predict drivers' recognition performance under day or night conditions. Optom Vis Sci 82, 698-705.

Wright, A., Reddick, A., Schwartz, S., Ferguson, J., Aleman, T., Kellner, U., Jurklies, B., Schuster, A., Zrenner, E., Wissinger, B., Lennon, A., Shu, X., Cideciyan, A., Stone, E., Jacobson, S., Swaroop, A., 2004. Mutation analysis of NR2E3 and NRL genes in Enhanced S Cone Syndrome. Hum Mutat 24, 439-400.

Wutz, K., Sauer, C., Zrenner, E., Lorenz, B., Alitalo, T., Broghammer, M., Hergersberg, M., de la Chapelle, A., Weber, B., Wissinger, B., Meindl, A., Pusch, C., 2002. Thirty distinct CACNA1F mutations in 33 families with incomplete type of XLCSNB and Cacna1f expression profiling in mouse retina. Eur J Hum Genet 10, 449-456. 
Yamamoto, S., Hayashi, M., Takeuchi, S., 1999. Electroretinograms and visual evoked potentials elicited by spectral stimuli in a patient with enhanced S-cone syndrome. Jpn J Ophthalmol 43, 433-407.

Zeitz, C., van Genderen, M., Neidhardt, J., Luhmann, U., Hoeben, F., Forster, U., Wycisk, K., Matyas, G., Hoyng, C., Riemslag, F., Meire, F., Cremers, F., Berger, W., 2005. Mutations in GRM6 cause autosomal recessive congenital stationary night blindness with a distinctive scotopic $15-\mathrm{Hz}$ flicker electroretinogram. Invest Ophthalmol Vis Sci 46, 4328-4335. 


\section{List of Figures}

1 Retinitis pigmentosa, in a child showing the early development of a pigmentary retinopathy with optic disc pallor and retinal arteriolar narrowing (reprocuced with permission from reference (Spalton et al., 2005)). . . . . . 7

2 Retinitis pigmentosa, the fundus appearance in early disease may be variable sometimes including mild pigment epithelial atrophy in the mid-periphery and small white dots at the level of the RPE. The typical bone spicule pigment deposition is typically seen later in the disease. (reproduced with permission from reference (Spalton et al., 2005)). . . . . . . . . . . . . . . 8

3 Retinitis punctata albescens, multiple white deposits scattered throughout the retina are seen alongside macular atrophy. (reproduced with permission from reference (Spalton et al., 2005)). . . . . . . . . . . . . . . . . . . 11

4 Fundus albipunctatus. The characteristic fundus appearance with multiple white dots scattered over the retina with macular sparing is shown (reproduced with permission from reference (Spalton et al., 2005)). . . . . . . . . 15

5 Sorsby fundus dystrophy, there is widespread RPE atrophy with an island of RPE preserved centrally. The optic disc is atrophied and the yellowishwhite deposits represent drusen. (reproduced with permission from reference (Spalton et al., 2005)). . . . . . . . . . . . . . . . . . . . . . 2

\section{List of Tables}

1 Characteristics of the Nyktometer 500, Mesotest II and Kontrastometer (adapted from (, DOG)). 